\title{
The Effect of Metformin versus Vitamin E on the Testis of Adult Diabetic Albino Rats: Histological, Biochemical and Immunohistochemistry Study
}

\author{
Wardah Abdullah Alasmari' ${ }^{1}$ Eman Mohamed Faruk ${ }^{2}$, Mohammed A. S. Abourehab ${ }^{3,4}$, \\ Amal Mahmoud Elsafy Elshazly ${ }^{{ }^{*}}$, Naser A. El Sawy ${ }^{6}$ \\ ${ }^{1}$ Department of Anatomy, Faculty of Medicine, Umm Al Qura University, Mecca, KSA \\ ${ }^{2}$ Department Histology and Cell Biology, Faculty of Medicine, Benha, Egypt \\ ${ }^{3}$ Department of Pharmaceutics, Faculty of Pharmacy, Umm Al-Qura University, Mecca, KSA \\ ${ }^{4}$ Department of Pharmaceutics, Faculty of Pharmacy, Minia University, Minia, Egypt \\ ${ }^{5}$ Department Anatomy and Embryology, Faculty of Medicine, Benha, Egypt \\ ${ }^{6}$ Department of Anatomy \& Embryology, Faculty of Medicine, Zagazig University, Ash Sharqiyah, Egypt \\ Email: *naser_elsawy@ymail.com
}

How to cite this paper: Alasmari, W.A., Faruk, E.M., Abourehab, M.A.S., Elshazly, A.M.E. and El Sawy, N.A. (2018) The Effect of Metformin versus Vitamin E on the Testis of Adult Diabetic Albino Rats: Histological, Biochemical and Immunohistochemistry Study. Advances in Reproductive Sciences, 6, 113-132.

https://doi.org/10.4236/arsci.2018.64010

Received: September 16, 2018 Accepted: November 10, 2018 Published: November 13, 2018

Copyright $\odot 2018$ by authors and Scientific Research Publishing Inc. This work is licensed under the Creative Commons Attribution International License (CC BY 4.0).

http://creativecommons.org/licenses/by/4.0/ (c) $(1)$

\begin{abstract}
Background: Impairment of testicular function is one of complications of Diabetes mellitus (D.M) and this may result from increased oxidative stress. Vitamin E (Vit E) has antioxidant properties. Objective: To determine the microscopic changes in the diabetic testis with metformin alone or with Vit $\mathrm{E}$ and which of them are better to preserve the testicular structure. Materials and Methods: Fifty adult albino rats, were equally divided into five groups: Group 1: control group; group 2: diabetic group (diabetes was induced by (65 $\mathrm{mg} / \mathrm{kg}$; i.p) single dose of streptozotocin (STZ); group 3: vit.E-treated diabetic group ( $200 \mathrm{mg} / \mathrm{kg} /$ day) ip; group 4: Metformin-treated diabetic group (100 $\mathrm{mg} / \mathrm{kg} /$ day) and group 5 Metformin and vit.E-treated diabetic group for eight weeks. Levels of testosterone, insulin and blood sugar were analyzed and testes specimens were prepared for light microscope and immunohistochemical detection of androgen receptor (AR) and caspase-3. Results: In diabetic group showed irregular seminiferous tubules with depletion, separation, vacuolation of the spermatogenic cells with perivascular and intertubular fibrosis also, the mean diameter of tubules significantly decreases. There are negative immunoexpressions of AR with positive caspase-3. Sections of metformin treated diabetic group showed incomplete or partial regeneration of germ cells while in group 4 and 5 showed almost complete regeneration of spermatogenic cells with increase in mean diameter of tubules, significantly in-
\end{abstract}


creases in AR and decreases in caspase-3 expression. Conclusion: D.M produce damage in the testicular tissue and the concomitant administration of vit-E with metformin was shown better effect than metformin alone.

\section{Keywords}

Diabetes Mellitus, Antioxidant, Testicular Structure

\section{Introduction}

Diabetes mellitus is one of chronic common diseases and was taken as one of five causes of death [1]. Some studies explained that increased blood glucose leads to increase oxidative stress that creates diabetic complication [2]. In diabetic patient there are decreases in testosterone level that cause marked reduction in gonadal weight and decreases in sperm count and distorted of testis basement membrane [3] [4]. Using antioxidant in order to outcome the oxidative effect of hypoglycemia [5] [6], as antioxidants can prevent the testicular damage in rodents as shown in some reports [7]. Vit.E is an antioxidant drug having a very good effect on reversing the oxidative stress effect of diabetes [8]. Also Vit.E has many effects other than as antioxidant, antihypertensive hepato and reproductive protective role [9] [10]. Some studies showed that Vit.E can decrease the oxidative stress in testis by decreasing lipid peroxidation in the testis of rats when they exposed to cigarette smoke [6] [11]. Also combined administration of antidiabetic drug with antioxidants can make synergistic effect on other organs as kidney, pancreases and this was reported by [6].

Metformin is one of hypoglycemic drugs used in treatment of diabetes and its action done by increasing insulin sensitivity and allow easily passing of glucose in hyperglycemic state [12]. Metformin is also used as medical treatment in polycystic ovary due to its effects on ovarian size and its outcome in male fetuses' gonads were reported [13] [14]. Androgen hormone is important in maintenance and maturation of spermatogenesis in testis [15]. The target cells for the androgen receptor (AR) are the nuclei of Leydig, Sertoli and myoid cells in rat testes [16]. Caspase- 3 is one of markers used to detect cell apoptosis and germinal cells arrest because increasing its level indicated deterioration of DNA synthesis [17] [18]. Here in current study, we study and compare the effect of Vit.E (as an antioxidant) alone or co-administration with MF (as a hypoglycemic drug) in testicular damage caused by diabetes.

\section{Material and Methods}

\section{1) Drugs}

Streptozotocin (diabetic drug) was purchased from Sigma-Aldrich, CHEMIE, GmbH, Germany; Lot No. SLBJ7785V. Vitamin E $( \pm)-\alpha$-Tocopherol was purchased from Sigma-Aldrich, CHEMIE, GmbH, Germany EC No. 2334660, Lot 
No. RA20270; Metformin HCl; A free gift from Medical Union Pharmaceuticals Co. (MUP); Abosultan, Ismailia, Egypt, Batch No. 2014000594 Free Sample.

Streptozotocin was prepared freshly on the day of experiment. Vitamin E was dissolved and diluted in corn oil and was used in experiment [19].

\section{2) Animals}

Healthy, fifty adult male albino Wistar rats weighing $250 \pm 20$ g were purchased from the Animal House, Faculty of Medicine, Um Al-Qura University. The animals were kept under standard normal conditions of temperature $\left(22^{\circ} \mathrm{C}\right.$ $\left.\pm 2^{\circ} \mathrm{C}\right)$, light (12 h light $/ 12 \mathrm{~h}$ dark) and humidity (45\%), for one week as an acclimatization period to accommodate the experiment conditions. During this period, animals were fed with a standard rat's pellet diet and had free access to tap water ad libitum. All animal procedures experiment was done according to the standards for the care and use of laboratory animals, approved by the university scientific research ethics committee for experimental animals at Faculty of Medicine, Um Al-Qura University. They randomly equally divided into 5 groups and each group was housed in separate cages.

\section{3) Induction of Diabetes Mellitus}

Animals of group 2, 3, 4, 5 were overnight fasted and diabetes was induced by a single intraperitoneal (i.p) injection of Streptozotocin (STZ) in a dose of 65 $\mathrm{mg} / \mathrm{kg}$ body weight dissolved in $0.1 \mathrm{M}$ citrate buffer ( $\mathrm{pH} 4.5$ ) as freshly prepared according to [20]. To avoid hypoglycemic mortality that can be done by initial drug dose, $5 \%$ glucose fluid were given to animals for $24 \mathrm{~h}$ following induction of diabetes the animals [21]. Plasma glucose was determined using an automated glucose analyzer device; Glucometer (One Touch Basic, Lifescan J\&J, USA) to confirm the induction of diabetes after $48 \mathrm{~h}$ after the dose of STZ, where blood was collected from tail rat vein using $24 \mathrm{G}$ needles [22]. Normal rats (Control non diabetic group) were injected intraperitoneal (i.p) with the same volume of $0.1 \mathrm{M}$ citrate buffer solution [23].

\section{4) Experimental Design}

Fifty rats were randomly equally divided into 5 groups each consists of 10 rats and treated as following.

Group I: Normal control non diabetic rats, injected intraperitoneal (i.p) with the same volume of $0.1 \mathrm{M}$ citrate buffer solution.

Group II: Control Diabetic rats, received daily oral dose of distilled water.

Group III: diabetic rats treated with metformin at a dose $(100 \mathrm{mg} / \mathrm{kg}$ body weight/day) [24].

Group IV: Diabetic rats treated with Vitamin E at a dose $(200 \mathrm{mg} / \mathrm{kg}$ body weight/day) [25].

Group V: Diabetic rats treated with combined metformin and Vitamin E at a doses of (100 mg/kg body weight/day) and ( $200 \mathrm{mg} / \mathrm{kg}$ body weight/day) respectively.

Treatments were administered once daily by oral gavage started at the $3^{\text {rd }}$ day after induction of diabetes for eight weeks [26]. Body weight (g) and fasting blood glucose concentrations were recorded 1 day before STZ-treatment and 
then periodically every two weeks in overnight fasting animals.

Then, overnight fasting rats were anesthetized with diethyl ether and blood samples were collected for various biochemical estimations from rat tail vein in which serum was separated by centrifugation at $2400 \mathrm{rpm}$ for $20 \mathrm{~min}$ at $4^{\circ} \mathrm{C}$ [19] and stored at $-20^{\circ} \mathrm{C}$ until further biochemical parameters investigation.

\section{a) Body weight}

Body weight was recorded 1 day before STZ-treatment and periodically every week during the study period and at the end of the study on overnight fasted animals.

\section{b) Serum Blood Glucose and Insulin Concentrations}

Fasting blood glucose level analysis was done by using glucometer (One Touch Basic, Lifescan J \& J, USA). According to the manufacturer protocol serum insulin, was determined with Enzyme-Linked Immunosorbent Assay (ELISA) using specific commercial rat ELISA diagnostic kits.

\section{c) Serum Testosterone, FSH and LH Levels}

Serum testosterone, Follicle Stimulating Hormone (FSH) and Luteinizing Hormone (LH) levels were measured ELISA using specific commercial rat ELISA diagnostic kits according to the manufacturer protocol.

\section{d) Serum Lipid Profile}

Total Cholesterol (TC), serum Triglycerides (TG), High Density Lipoprotein-cholesterol (HDL-c), and low density lipoprotein-cholesterol (LDL-c) levels were measured photometrically by standard enzymatic calorimetric method, using commercial kits according to manufacturer instructions.

e) Testicular Redox Evaluation (In vivo antioxidant activity in testes homogenates)

In order to antithesis the rats they were injected by pentobarbital injection (60 $\mathrm{mg} / \mathrm{kg}$ ) [15] then sacrificed and testes were taken in normal saline. Then we removed the capsule of the testes and homogenized using an Ultra-Turrax homogenizer. We homogenizing testicular tissues in $1.15 \% \mathrm{KCl}$ solution to obtain a $10 \%$ homogenate then the $10 \%$ of homogenates were added to $6.7 \mathrm{mM}$ phosphate buffer ( $\mathrm{pH} \mathrm{7.4)}$ and centrifuged at $6000 \mathrm{rpm}$ for $10 \mathrm{~min}$, finally the supernatant was used to measure the lipid peroxidation were detected. Reduced glutathione (GSH) was estimated by the method done by Sedlak and Lindsay [27]. Catalase (CAT) activity was measured by the method done by Aebi [28]. Superoxide dismutase (SOD) was measured by the method done by Misra and Fridovich [29]. The product of the reaction between malondialdehyde (MDA) was calculated by a modified method of Ohkawa et al. [30]. Superoxide Dismutase (SOD), reduced glutathione (GSH), Malondialdehde (SOD), reduced glutathione (GSH), Malondialdehyde (MDA) Malondialdehyde (MDA) and catalase (CAT) activities were estimated by enzymatic method, using commercial kits according to the manufacturer instruction.

\section{f) Histological examination}

After eight weeks of experiment, the weight of all animals were measured the 
rats weighted, and then anesthetized by pentobarbital injection $(60 \mathrm{mg} / \mathrm{kg})$ [31] and sacrificed. No deaths occurred during the study in any of the groups. The left testes were taken from all animal groups and fixed in Bouin's solution to be processed for paraffin sections ( $5 \mu \mathrm{m}$ in thickness). The sections were papered for staining with the following:

i) Hematoxylin \& Eosin (H \& E) for histological examinations [32].

ii) Masson's trichrome stain for collagen fibers detections [32].

iii) Immunohistochemically studies to detect androgen receptors (AR) in which the polyclonal (rabbit) anti-ARs (PA1-111A; Affinity Bioreagents Inc., Colorado, Golden, USA) were used as the primary antibodies. Brown color reaction was detected in the nuclei of Sertoli cells, and Leydig cells. Counterstained with hematoxylin was done to all sections [33]. Negative control sections were preparing as the same method was applied, but PBS was added instead of primary antibody (PA1111A). Sections of the prostatic adenocarcinoma were considered as positive control tissues, as strong positive androgen receptor immunoreaction in both the nucleus and cytoplasm of the malignant cells [34].

The (caspase-3) to examine the apoptotic cellular changes Caspase- 3 antibody, which is a rabbit polyclonal antibody (CPP32) Ab-4 (Thermo Fisher Scientific, Fermont, California, USA). A standard avidin-biotin peroxidase complex system was used to detection of caspase- 3 using according to the kit used (Neomarkers) (34) Sections were counterstained with hematoxylin [33].

iv) Evaluation of spermatogenetic activity: Johnson method was done for histological spermatogenetic score [35] from 1 - 10 according to presence of germ cells and Sertoli cells:

v) Morphometric study was done by using "OlympusBX40" image analyzer computer system (Cambridge, England) in Histology Department, Faculty of Medicine, Cairo University. Measurement and study of 10 non-over lapping fields for each animal at $\times 400$ power to determine the following:

a. The mean seminiferous tubule diameter, were randomly examined and the tubule diameters of the ten most circular seminiferous tubules from each specimen were measured by using Sudaman method in which the average of the big and small diameter of tubule was calculated using the formula magnification [36].

b. The area $\%$ for the mission stained collagen fibers around seminiferous tubules.

c. The Area\% for the immunohistochemical stains of caspase-3 and AR in the cells of the seminiferous tubules.

d. By a calibrated ocular lens of micrometer (Germany) on light microscope we calculation the number of Sertoli cells/tubule and number of STs/field and the number of Leydig cells $/ 100 \mu \mathrm{m}^{2}$.

\section{g) Statistical analysis}

All obtained data were expressed as (Mean \pm SEM): One-way analysis of variance (ANOVA) was used to statistical analysis of collected data. $\mathrm{p}<0.001$ was considered statistically significant. Calculations were done on SPSS IBM, united states (version 16 windows) software [37]. 


\section{Results}

\subsection{Effects on Body Weight}

The effects of different treatment on the rats' body weight are illustrated in Table 1 . In normal control animals, body weights were not significantly $(p>0.05)$ different (the initial and final of body weight), in spite, there was a slight weight gain. As noticed in the tabulated results, at the end of the study period ( 8 weeks), non-treated diabetic control rats (Gp II) showed a significant ( $\mathrm{p}<0.001)$ loss in body weight compared to the normal control rats (Gp I), where, diabetic rats showed a progressive fall in the body weight and the decrease in body weight was observed after two weeks of induction of diabetes in rats, and this fall in weight continued till the end of the experiment. Treated animals with metformin showed partial recovery in body weight with different extent during the experimental period but there were a non-significant $(p>0.05)$ in mean body weight between metformin-treated rats and the diabetic control rats. While, treatment with vitamin $\mathrm{E}$ led to a significant $(\mathrm{p}<0.001)$ increase in body weight more than the normal control rats. On the other hand, combined treatment with both metformin and vitamin E showed a significant recovery of the body weight compared to the diabetic control rats, weight gain was observed in the treated rats.

\subsection{Effect on Blood Glucose and Insulin Concentrations}

Fasting blood glucose concentrations of the treated experimental animals at different time intervals during the experiment period are shown in Table 2. It is

Table 1. Effect of different treatments (8 Weeks) on body weight (g).

\begin{tabular}{ccc}
\hline GP & Initial Body Weight $(\mathrm{g})$ & Final Body Weight $(\mathrm{g})$ \\
\hline Normal Control & $255.00 \pm 2.98$ & $266.40 \pm 3.11$ \\
Diabetic Control & $257.40 \pm 2.66$ & $159.20 \pm 3.09$ \\
Metformin & $254.60 \pm 2.42$ & $177.80 \pm 2.69^{\mathrm{b}}$ \\
Vitamin E & $259.00 \pm 3.27$ & $249.60 \pm 2.38^{\mathrm{a}, \mathrm{b}}$ \\
Combination & $252.60 \pm 2.77$ & $268.20 \pm 1.86^{\mathrm{b}}$ \\
\hline
\end{tabular}

Values are expressed as means $( \pm \mathrm{SEM})$. ${ }^{\mathrm{a}}$ Non-significant difference $(\mathrm{p}>0.05)$ compared with control groups. ${ }^{b}$ Significant difference $(\mathrm{p}<0.001)$ between treatment and control groups.

Table 2. Effect of different treatments on Fasting Blood Glucose levels (mg/dL).

\begin{tabular}{cccccc}
\hline Groups & 0 Week & 2 Weeks & 4 Weeks & 6 Weeks & 8 Weeks \\
\hline Normal Control & $93.80 \pm 1.16$ & $92.80 \pm 0.73$ & $93.20 \pm 1.39$ & $94.40 \pm 0.93$ & $94.60 \pm 0.81$ \\
Diabetic Control & $95.40 \pm 0.75$ & $345.00 \pm 2.35$ & $389.60 \pm 5.11$ & $434.60 \pm 1.94$ & $424.00 \pm 2.00$ \\
Metformin & $97.20 \pm 1.02$ & $315.80 \pm 1.36$ & $234.40 \pm 2.21$ & $191.40 \pm 1.97$ & $122.80 \pm 0.97^{\mathrm{b}}$ \\
Vitamin E & $95.80 \pm 1.43$ & $334.00 \pm 1.92$ & $279.20 \pm 1.96$ & $222.80 \pm 2.56$ & $169.60 \pm 1.47^{\mathrm{b}}$ \\
Combination & $94.60 \pm 1.36$ & $285.20 \pm 2.48$ & $214.20 \pm 2.08$ & $139.80 \pm 1.50$ & $101.20 \pm 1.16^{\mathrm{b}, \mathrm{a}}$ \\
\hline
\end{tabular}

Values are expressed as means $\left( \pm\right.$ SEM). ${ }^{a}$ Non-significant difference $(p>0.05)$ compared with control groups. ${ }^{\mathrm{b}}$ Significant difference $(\mathrm{p}<0.001)$ between treatment and control groups. 
clear from the tabulated results that, in the normal control animals, treatment with the water alone did not significantly affect the blood glucose concentrations compared to the diabetic control group animals. While, the STZ-treated rats had increase in the blood glucose concentrations, and the values were significantly higher $(\mathrm{p}<0.001)$. Rats treated with metformin showed a significant lowering of the blood glucose concentration $(\mathrm{p}<0.001)$ compared to the diabetic rats. From the results, it is clear that treatment with vitamin $\mathrm{E}$ alone showed a marked decrease in blood glucose concentration $(\mathrm{p}<0.001)$ compared to the diabetic rats. While, treatment with a combination of metformin and vitamin $\mathrm{E}$ showed the most effective decrease in the blood glucose concentration, compared to the diabetic rats and the treated groups, either metformin or the vitamin $\mathrm{E}$ alone. This result augments the hypothesis of the proposal, for the synergistic effects of metformin with vitamin E against STZ-induced diabetes, as the combination treatment, tended to nearly normalize the fasting blood glucose concentration, and there was no significant difference $(\mathrm{p}>0.05)$ compared to the normal non-diabetic rats. STZ drug lead to reduce the serum insulin level compared to normal control rats. Treatment with metformin or vitamin $\mathrm{E}$ either alone or in combination, significantly $(\mathrm{p}<0.001)$ increased the serum insulin levels compared to the non-treated diabetic rats Table 3.

\subsection{Effect on Serum Testosterone, FSH and LH Levels}

As shown in Table 4, diabetes induced by STZ, significantly $(\mathrm{p}<0.001)$ reduced serum LH, FSH and testosterone levels compared to the normal control rats.

Table 3. Effect of different treatments on serum insulin concentrations $(\mu \mathrm{U} / \mathrm{mL})$.

\begin{tabular}{ccc}
\hline Groups & 0 Week & $\mathbf{8}$ Weeks \\
\hline Normal Control & $38.64 \pm 0.23$ & $38.66 \pm 0.37$ \\
Diabetic Control & $38.93 \pm 0.49$ & $12.07 \pm 0.26$ \\
Metformin & $38.66 \pm 0.38$ & $31.68 \pm 0.44^{\mathrm{b}}$ \\
Vitamin E & $38.49 \pm 0.27$ & $29.69 \pm 0.52^{\mathrm{b}}$ \\
Combination & $38.94 \pm 0.22$ & $37.26 \pm 0.33^{\mathrm{a}, \mathrm{b}}$ \\
\hline
\end{tabular}

Values are expressed as means $( \pm \mathrm{SEM})$. ${ }^{\mathrm{a}}$ Non-significant difference $(\mathrm{p}>0.05)$ compared with control groups. ${ }^{b}$ Significant difference $(\mathrm{p}<0.001)$ between treatment and control groups.

Table 4. Effect of different treatments on rats gonadotrophic and sexual hormones.

\begin{tabular}{cccc}
\hline GP & Testosterone. $(\mathrm{ng} / \mathrm{ml})$ & LH (IU/L) & FSH (IU/L) \\
\hline Normal Control & $3.59 \pm 0.05$ & 0.58 & $0.83 \pm 0.01$ \\
Diabetic Control & $0.53 \pm 0.02$ & 0.18 & $0.21 \pm 0.03$ \\
Metformin & $1.83 \pm 0.04$ & 0.38 & $0.58 \pm 0.03$ \\
Vitamin E & $2.57 \pm 0.05$ & 0.41 & $0.55 \pm 0.03$ \\
Combination & $3.41 \pm 0.06$ & 0.53 & $0.79 \pm 0.04$ \\
\hline
\end{tabular}

Values are expressed as means $\left( \pm\right.$ SEM) for all groups. ${ }^{\text {an } I n s i g n i f i c a n t ~ d i f f e r e n c e ~}(\mathrm{p}>0.05)$ compared with control groups. ${ }^{b, c}$ Significant difference $(p<0.001)$ in the same row between treatment and control groups. 
Treatment with metformin or vitamin E alone partially increased the testosterone levels but not to the normal values, and there was significant difference ( $\mathrm{p}<$ 0.001 ) compared to the normal control rats. While, treatment with a combination of vitamin $\mathrm{E}$ with metformin showed recovery of the $\mathrm{FSH}, \mathrm{LH}$ and testosterone normal levels, and non-significant difference $(\mathrm{p}>0.05)$ were obtained compared to the normal control rats, while a significant difference $(\mathrm{p}<0.001)$ were obtained compared to the non-treated control diabetic rats.

\subsection{Biochemical Studies (Serum Lipid Profile): Table 5}

From the results, it can be observed that, the untreated diabetic control rats were characterized by a significant difference in the biochemical parameters as total cholesterol (TC), low density lipoprotein-cholesterol (LDL-c), and triglycerides (TG), compared to the normal control rats. While, diabetic rats showed a significant ( $\mathrm{p}<0.001$ ) decrease in the high density lipoprotein-cholesterol (HDL-c) level in comparison to the normal control rats. Treatment with metformin normalize the biochemical parameters compared to the control diabetic rats. From the results, it could be observed that, vitamin E treatment almost tend to normalize the biochemical parameters in the treated rats and there is no-significant difference $(p>0.05)$ compared to the normal non-diabetic rats at the end of experiment, where rats in vitamin $\mathrm{E}$ and combination treated groups showed near normal levels of TC, TG, HDL-c, LDL-c.

\subsection{Effect on of the Oxidative/Antioxidant Enzymes (Table 6)}

The testicular antioxidant activity of CAT, SOD, and GSH in the STZ-treated

Table 5. Effect of different treatments on lipid profile levels.

\begin{tabular}{ccccc}
\hline GP & TG $(\mathrm{mg} / \mathrm{dL})$ & HDL-c $(\mathrm{mg} / \mathrm{dL})$ & LDL-c $(\mathrm{mg} / \mathrm{dL})$ & TC $(\mathrm{mg} / \mathrm{dL})$ \\
\hline Normal Control & 61.81 & 49.15 & 65.58 & 93.37 \\
Diabetic Control & 155.48 & 21.37 & 144.14 & 194.03 \\
Metformin & 97.23 & 32.06 & 98.63 & 143.52 \\
Vitamin E & 83.63 & 44.62 & 74.39 & 122.72 \\
Combination & 72.24 & 47.82 & 68.15 & 104.37 \\
\hline
\end{tabular}

Values are expressed as means $\left( \pm\right.$ SEM). ${ }^{a}$ Non-significant difference $(p>0.05)$, compared with control groups. ${ }^{b, c}$ Significant difference $(\mathrm{p}<0.001)$ between treatment and control groups.

Table 6. Effect of different treatments on of the oxidative/antioxidant enzymes activities in testicular tissues.

\begin{tabular}{ccccc}
\hline Groups/parameters & SOD (U/mg protein) & GSH (mmole/g protein) & MDA (nmol/mg protein) & CAT (mmple/min/mg protein) \\
\hline Normal Control & 169.28 & 6.62 & $0.95^{\mathrm{a}}$ & $35.92^{\mathrm{b}}$ \\
Diabetic Control & 73.19 & 2.52 & 3.66 & 1.23 \\
Metformin & 146.57 & 4.85 & 1.02 & 27.12 \\
Vitamin E & 151.16 & 5.83 & 0.97 & 30.24 \\
Combination & 164.14 & 6.56 & 36.76 \\
\hline
\end{tabular}

Values are expressed as means $\left( \pm\right.$ SEM). ${ }^{a}$ Non-significant difference $(\mathrm{p}>0.05)$, compared with control groups. ${ }^{b, c}$ Significant difference $(\mathrm{p}<0.001)$ between treatment and control groups. 
diabetic rats were significantly $(\mathrm{p}<0.001)$ decreased, on the contrast, level of MDA was significantly $(\mathrm{p}<0.001)$ increased compared to the normal control rats. The treatment of diabetic rats with metformin alone, significantly $(\mathrm{p}<$ 0.001) enhances the antioxidant parameters compared to the diabetic control rats. Treatment of diabetic rats with vitamin $\mathrm{E}$ alone led to a significant decrease in serum levels of lipid peroxidase (MDA), while, there are significant $(\mathrm{p}<$ 0.001) enhancement in the antioxidant enzyme activities (SOD, CAT and GSH) compared to the diabetic non-treated rats. While, treated diabetic rats with combination of metformin and vitamin $\mathrm{E}$, showed normalization of the parameters, and there were significant $(\mathrm{p}<0.001)$ difference compared to the diabetic non-treated rats.

\subsection{Histological and Immunohistochemical Results}

$\mathrm{H} \&$ E-stained sections of the testes of the control group showed many regular and rounded seminiferous tubules were separated by interstitial tissues which contain the polygonal Leydig cells with an acidophilic cytoplasm and tubules were lined by layers of spermatogenic cells and Sertoli cells. Sertoli cells were seen between spermatogenic cells resting on the basement membrane and have large ovoid nuclei (Figure 1(a)). The seminiferous tubules were lined by a regular basement membrane that had the spermatogenic cells which are spermatogonia, spermatocytes, spermatids, and finally mature sperm filling the lumen of the tubules. Primary spermatocytes are the largest spermatogenic cells (Figure 1(b)), while very thin collagen fibers showed around seminiferous tubules (Figure 1(c)). Positive Androgen receptor immunoexpression was found in the spermatogenic and Leydig cells (Figure 2(a)) while negative caspase-3 reaction in and between spermatogenic cells (Figure 2(b)).

In diabetic group, $\mathrm{H} \& \mathrm{E}$-stained sections of the testes revealed irregularity of some seminiferous tubules and the spermatogenic cells were separated from their basement membrane with presence of sign of degeneration as vacuolation of their cytoplasm and there were few numbers of pale vacuolated interstitial cells of Leydig. There were wide interstitial spaces between the tubules with dilated blood vessels (Figure 3(a) and Figure 3(b)). Collagen fibers were present around seminiferous tubules (Figure $3(\mathrm{c})$ ). Negative Androgen receptor immunoexpression was found in the spermatogenic and Leydig cells (Figure 4(a)), highly caspase- 3 positive reaction was seen in the cytoplasm of the spermatogenic cells as well as Leydig cells was observed (Figure 4(b)). In sections of metformin treated diabetic group, most of the seminiferous tubules appeared regular and lined by layers of spermatogenic cells with sperm in their lumen while, few of them were lined by degenerated spermatogenic cells (Figure 5(a) and Figure 5(b)). Moderate collagen fibers were observed in between tubules (Figure 5(c)). Moderate positive androgen receptor immunoexpression was seen in the spermatogenic and Leydig cells (Figure 6(a)), mild to moderate positive caspase-3 immunoexpression was seen in the spermatogenic and Leydig cells (Figure 6(b)). 


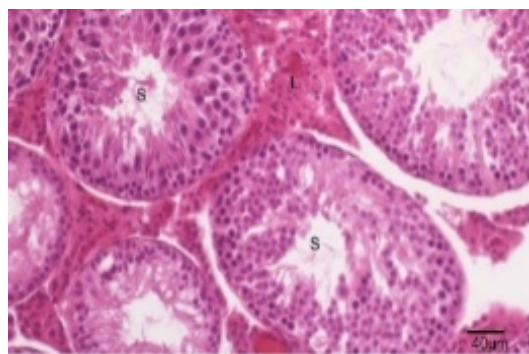

(a)

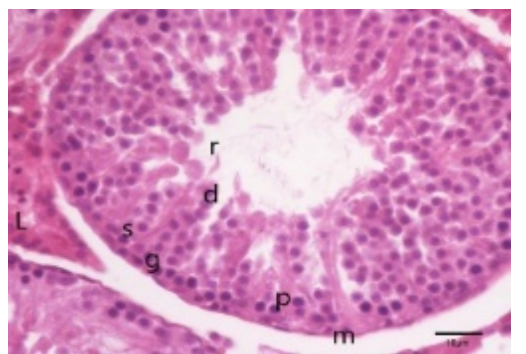

(b)

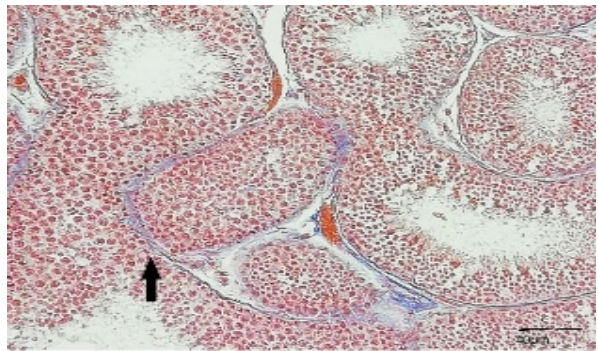

(c)

Figure 1. $\mathrm{H} \times \mathrm{E}$ and Masson's trichrome staining in testis of the control (a)-(c): (a) showing many seminiferous tubules (S) regularly closely packed and separated by interstitial tissue containing Leydig cells (L). The seminiferous tubules lined by spermatogenic epithelium resting upon regular basement membrane and formed of many layers of spermatogenic cells with sperms in the lumen; (b) showing spermatogenic cells, with sperms in the lumen (r). Spermatogonia (g), primary spermatocytes (P) with large nuclei, spermatids (d) with rounded nuclei and Sertoli cells (s) with oval nuclei. Note that Leydig cells (L)and myoid cell(m); (c) showing many minimal fine collagen fibers around seminiferous tubules (arrow). H\&E (a), ×200, (b), ×640 and (c)Masson's trichrome, $\times 200$.

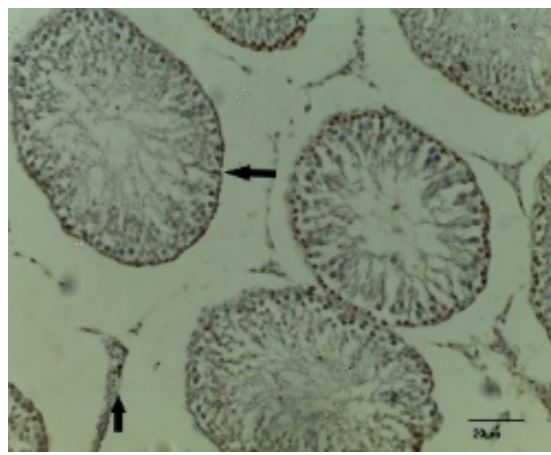

(a)

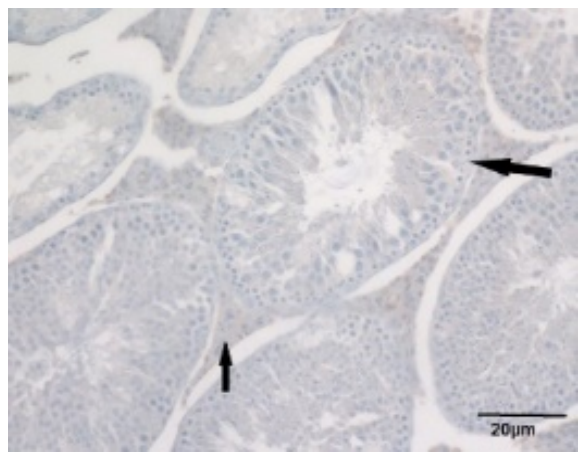

(b)

Figure 2. AR and caspase immunoexpressions showing seminiferous tubules with strong positive (AR) immunoexpression in the spermatogenic and Leydig cells (arrow). AR immunostaining, $\times 400$; (b) showing negative (caspase- 3 ) immunoexpression in the spermatogenic and Leydig cells (arrow). Caspase -3 immunostaining, $\times 400$.

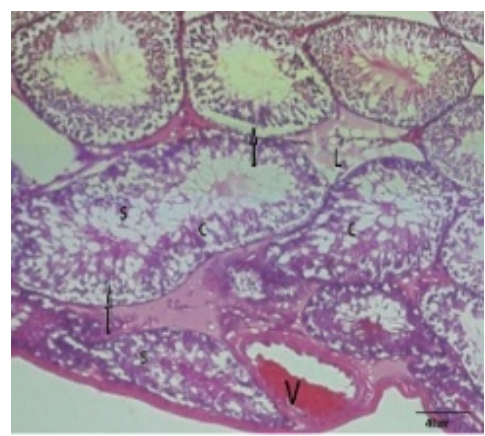

(a)

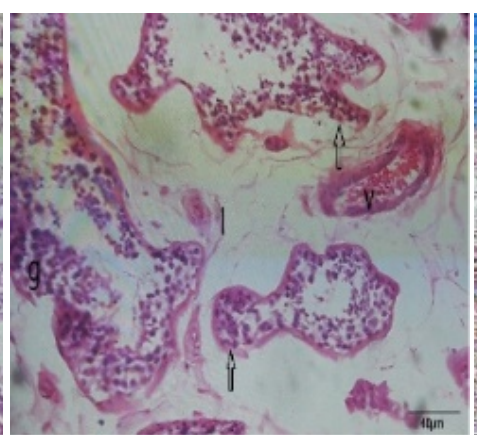

(b)

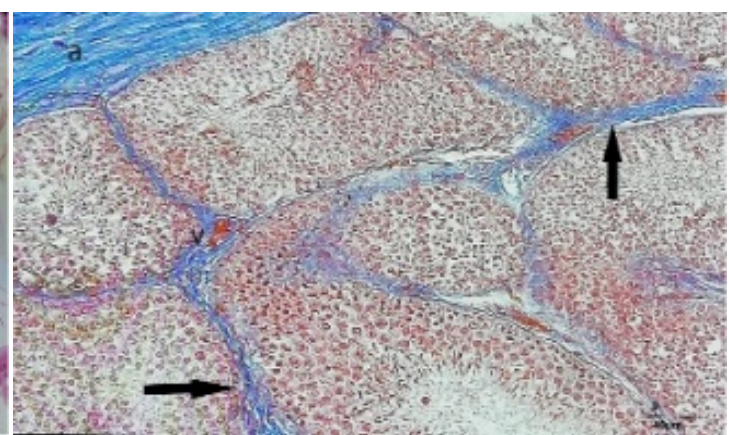

(c)

Figure 3. $\mathrm{H} \times \mathrm{E}$ and Masson's trichrome staining in testis of the diabetic untreated rat (a)-(c): (a) showing many irregular seminiferous tubules (S) with different shapes separated by wide interstitial tissue containing degenerated vaculated Leydig cells (L) and an acidophilic exudate and many vacuoles. Irregular seminiferous tubules showed degenerated and the spermatogenic cells were released to the lumen of tubules earlier (arrow). Notice congested blood vessels (v) and many vacuoles (c) in between the spermatogenic cells; (b) showing many irregular disorganized seminiferous tubules (S) separated by wide interstitial tissue (I) that contains congested blood vessels $(\mathrm{v})$. The tubules showed increase in germ cells in their lumen $(\mathrm{g})$. Notice many of the spermatodenic cells showed pyknotic nuclei (arrow); (c) showing coarse collagen fibers around seminiferous tubules(arrow), thick tunica albuginea (a) and perivascular (v). H\&E (a), ×200, (b), $\times 400$ and (c) Masson's trichrome, $\times 200$. 


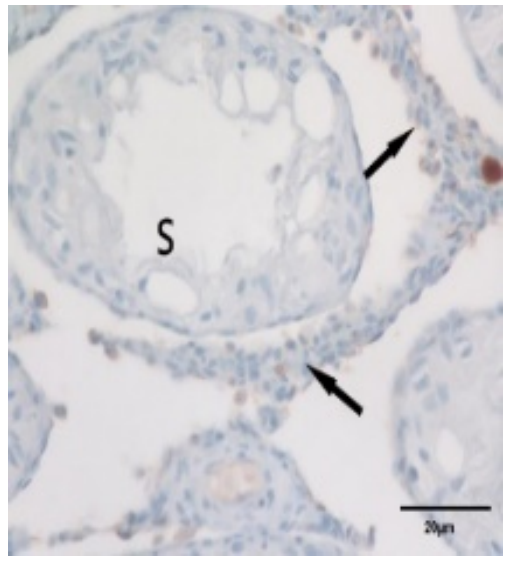

(a)

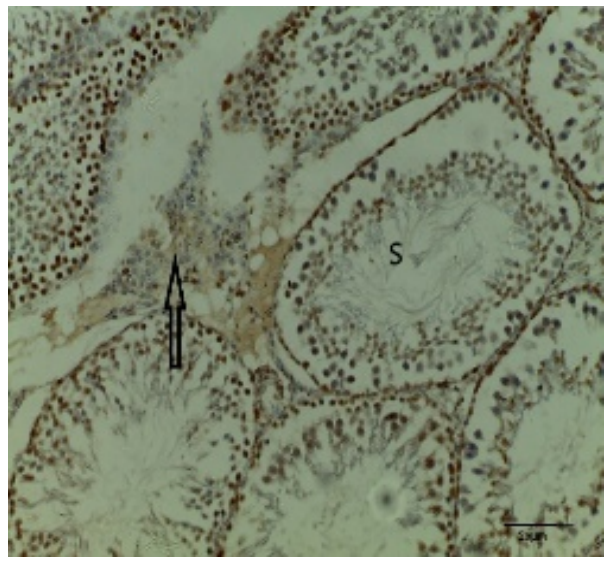

(b)

Figure 4. AR and caspase immunoexpressions in testis of a diabetic untreated rat ((a), (b)): (a) showing seminiferous tubules with negative (AR) immunoexpression in the spermatogenic (s) and mild (AR) immunexpression in Leydig cells (arrow). AR immunostaining, $\times 400$; (b) showing seminiferous tubules with strong positive (caspase-3) immunoexpression in the spermatogenic (s) and in Leydig cells (arrow). Caspase- 3 immunostaining, $\times 400$.

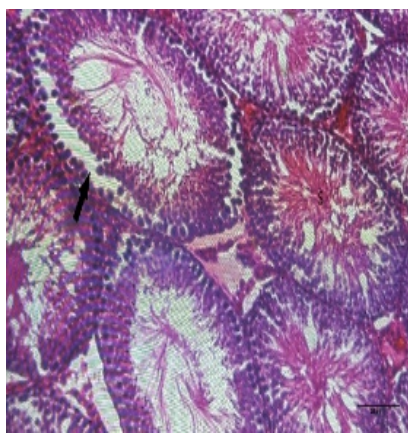

(a)

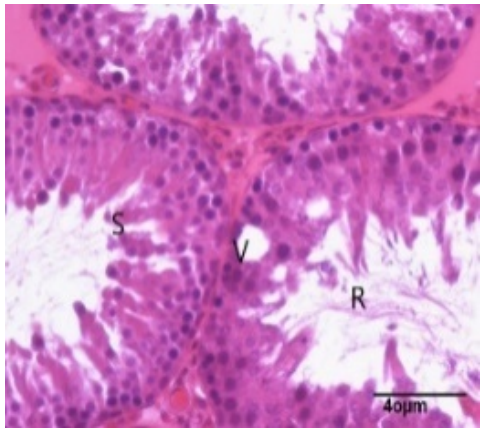

(b)

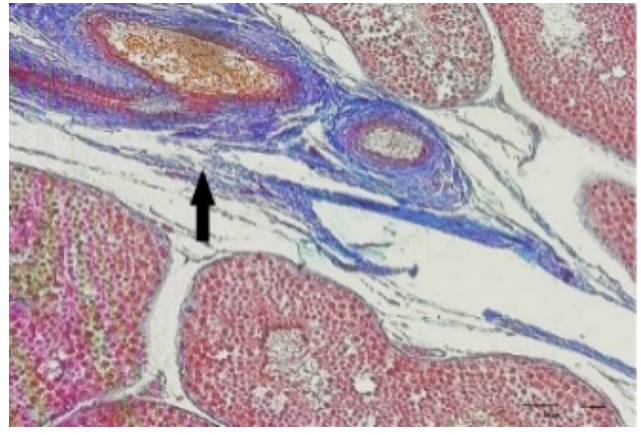

(c)

Figure 5. $\mathrm{H} \times \mathrm{E}$ and Masson's trichrome staining in testis of the rat treated with metformin (a)-(c): (a) showing apparent normal seminiferous tubules (S) some showing desquamation of spermatogenic cells from underline basement membrane(arrow); (b) showing the seminiferous tubules lined by several layers of spermatogenic cells (S). Notice that sperm in the lumen of some tubules $(\mathrm{R})$ and vaculations are present $(\mathrm{V})$; (c) showing mild collagen fibers accumulation around perivascular (arrow). H\&E (a), ×200, (b), ×400. and (c) Masson's trichrome, $\times 200$.

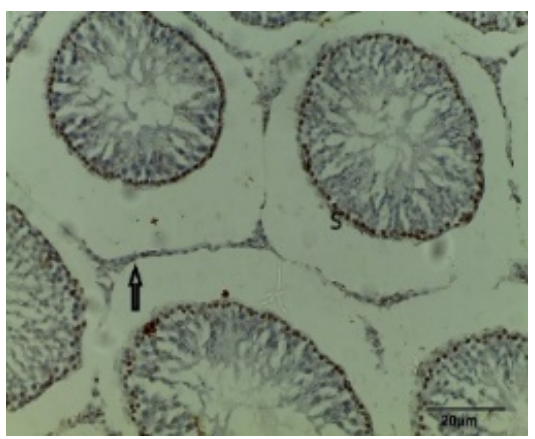

(a)

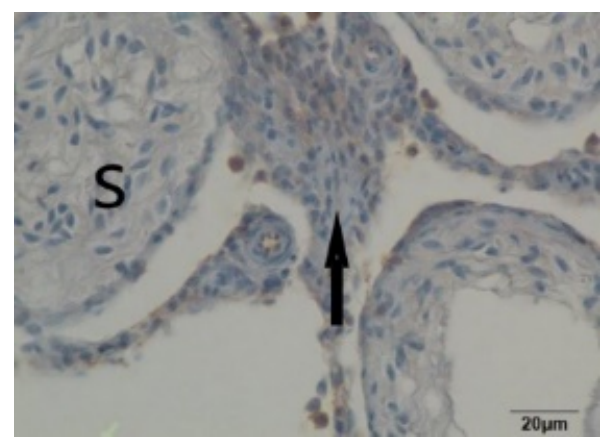

(b)

Figure 6. AR and caspase immunoexpressions in testis of a rat treated with metformin ((a), (b)): (a) showing seminiferous tubules with positive (AR) immunoexpression in the spermatogenic (s) and mild to moderate(AR)immunexpression in Leydig cells (arrow). AR immunostaining, $\times 400$; (b) showing seminiferous tubules with mild positive (caspase-3) immunoexpression in the spermatogenic (s) and moderate (caspase-3) immunexpression in Leydig cells (arrow). Caspase-3 immunostaining, $\times 400$. 
In vit-E treated diabetic group showed little number of seminiferous tubules had regular basement membrane and was lined by almost normal spermatogenic cells (Figure 7(a) and Figure 7(b)). Severe to moderate intertubular collagen fiber was observed (Figure $7(\mathrm{c})$ ). Moderate androgen receptor immunoexpression was found in the spermatogenic and Leydig cells (Figure 8(a)), mild positive caspase-3 immunoexpression was seen in the spermatogenic and Leydig cells (Figure $8(\mathrm{~b})$ ). In sections of metformin and vit-E treated diabetic group, the seminiferous tubules appeared regular and normal with spermatogonia and Sertoli cells were detected on their basement membranes, sperms also were detected in their lumen and between the seminiferous tubules there were loose vascular connective tissue with interstitial cells of Leydig (Figure 9(a) and Figure 9(b)). Minimal accumulation of collagen fibers between tubules was observed (Figure 9(c)). Severe to moderate androgen receptor immunoexpression was found in the spermatogenic and Leydig cells (Figure 10(a)). Mild positive immunoexpression caspase-3 was seen in the spermatogenic and Leydig cells (Figure 10(b)).

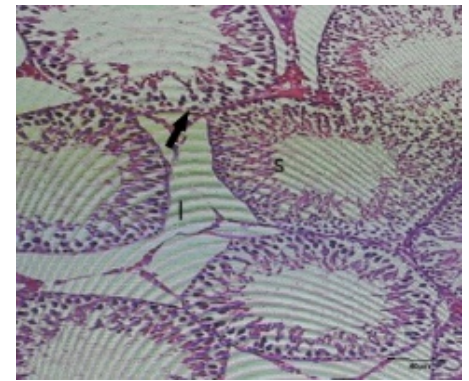

(a)

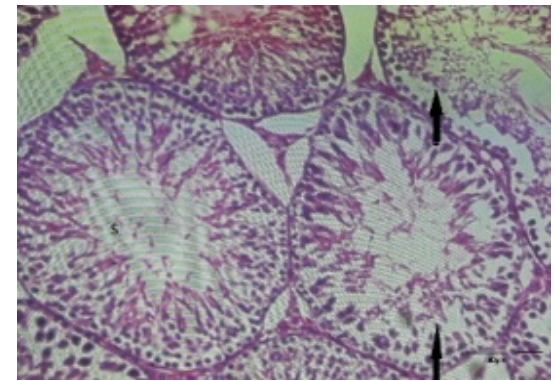

(b)

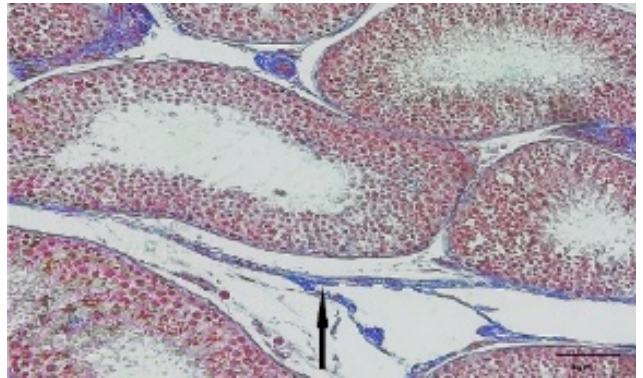

(c)

Figure 7. $\mathrm{H} \times \mathrm{E}$ and Masson's trichrome staining in testis of the rat treated with vitamin $\mathrm{E}$ (a)-(c): (a) showing apparent normal seminiferous tubules (S) with wide interstitial space (I). Notice that separation of spermatogenic cells from underlying basement membrane (arrow); (b) showing apparent normal seminiferous tubules (S) with disorganized spermatogenic cells in other tubules (arrow); (c) showing fine collagen fibers around seminiferous tubules (arrow). H \& E (a), ×200, (b), ×400 and (c) Masson's trichrome, $\times 200$

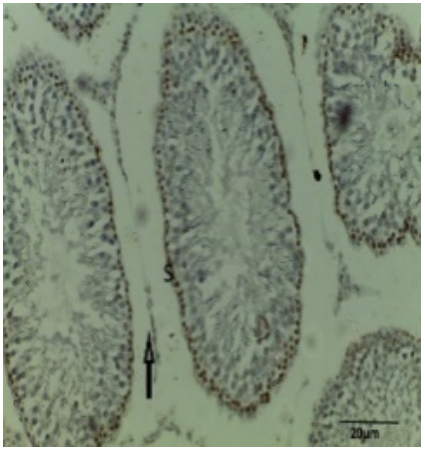

(a)

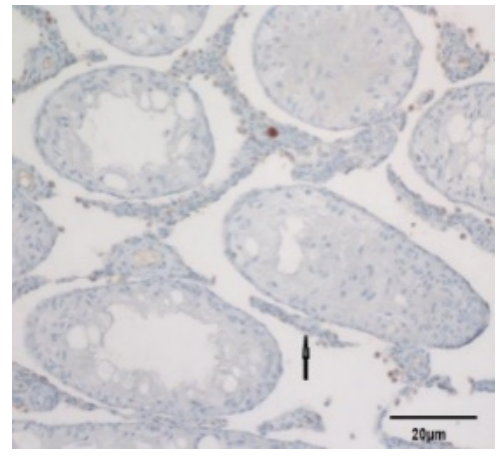

(b)

Figure 8. AR and caspase immunoexpressions in testis of a rat treated with vitamin $\mathrm{E}((\mathrm{a})$, (b)): (a) showing seminiferous tubules with mild to moderate positive (AR) immunoexpression in the spermatogenic (s) and mild (AR)immunexpression in Leydig cells (arrow). AR immunostaining, $\times 400$; (b) showing seminiferous tubules with mild (caspase- 3 ) immunoexpression in the spermatogenic (s) and mild (caspase-3) immunexpression in Leydig cells (arrow). Caspase-3 immunostaining, $\times 400$. 


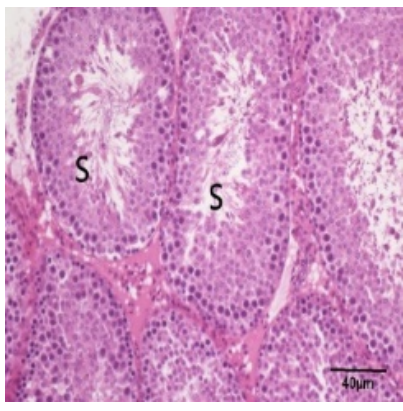

(a)

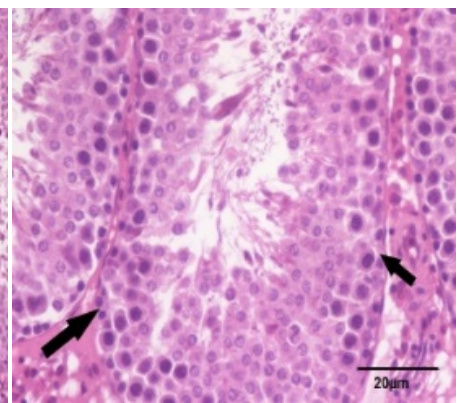

(b)

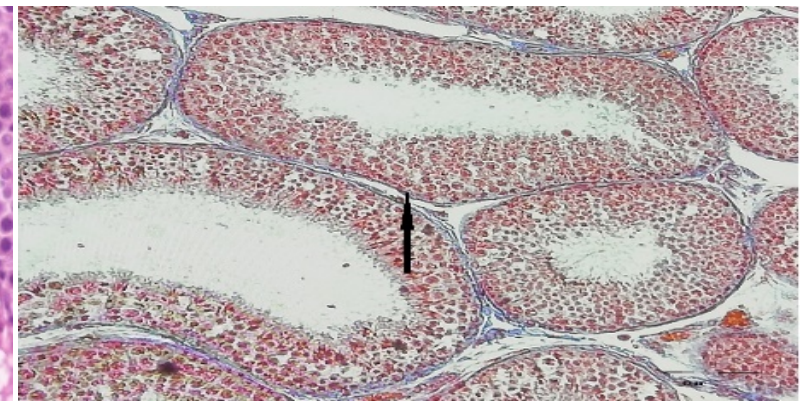

(c)

Figure 9. $\mathrm{H} \times \mathrm{E}$ and Masson's trichrome staining in testis of the rat treated with both metformin and vitamin $\mathrm{E}$ (a)-(c): (a) showing the seminiferous tubules as similar to that of the control group in structure (s); (b) showing seminiferous tubules (S) lined by more or less normal spermatogenic cells (arrow); (c) showing minimal fine collagen fibers around seminiferous tubules (arrow). H\&E (a), $\times 200,(b), \times 400$ and (c) Masson's trichrome, $\times 200$.

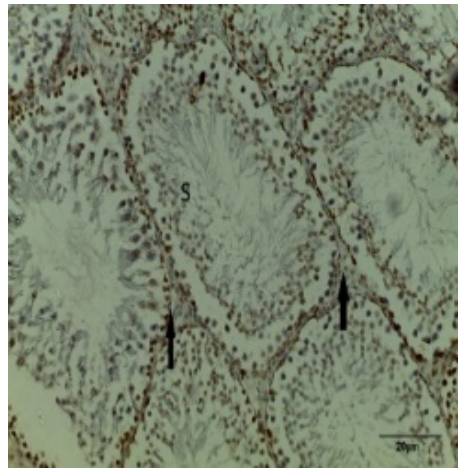

(a)

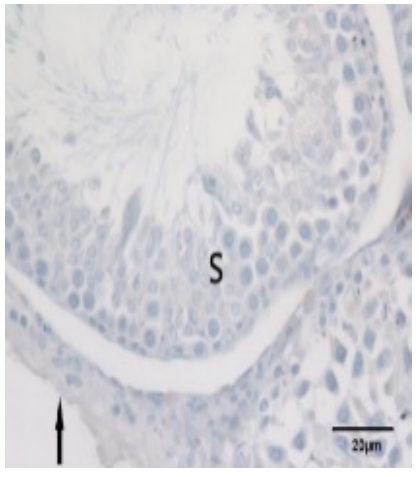

(b)

Figure 10. AR and caspase immunoexpressions in testis of a rat treated with both metformin and vitamin E ((a), (b)): (a) showing seminiferous tubules with strong positive (AR) immunoexpression in the spermatogenic (s) and positive (AR) immunexpression in Leydig cells (arrow). AR immunostaining, $\times 400$; (b) showing seminiferous tubules with negative (caspase-3) immunoexpression in the spermatogenic (s) and negative (caspase-3) immunexpression in Leydig cells (arrow). Caspase-3 immunostaining, $\times 400$.

\subsection{Morphometric Results}

The mean area $\%$ of collagen fibers and mean area $\%$ of caspase- 3 expression (Table 7 and Table 8). There was a significant decreased $(\mathrm{p} \leq 0.05)$ in collagen fibers accumulation and in caspase- 3 expression in group 3, 4 and 5 compared with group 1 and 2.

The mean diameter of seminiferous tubules in the diabetic group decreased in comparison to control and metformin treated diabetic rats $(\mathrm{p}<0.05)$. In vit-E treated diabetic rats, the diameter of seminiferous tubules was decreased but this reduction was not significant in comparison with the control group while co-treatment with metformin significantly elevated in comparison with the control group (Table 9). Spermatogenetic activity result according to Johnson score (Table 9): The scoring system done according to the Johnson criteria, significant decrease the diabetic group compared to that of the control group $(\mathrm{p}<0.05)$, whereas increases were observed in the Metformin-received diabetic group and Metformin and vit-E-treated diabetic group $(\mathrm{p}<0.01)$. The mean numbers 
W. A. Alasmari et al.

Table 7. Showing the mean area \%, SD of collagen fibers accumulation in all groups compared with control group.

\begin{tabular}{cccccc}
\hline Groups/parameters & $\begin{array}{c}\text { Control } \\
\text { group }\end{array}$ & $\begin{array}{c}\text { Diabetic } \\
\text { group }\end{array}$ & Diabetic + vit-E group & Diabetic + Metformin group & Diabetic + Metformin + vit - E group \\
\hline Mean area \% & $0.16 \%$ & $15.68 \%$ & $5.77 \%$ & $3.67 \%$ & $0.22 \%$ \\
SD \pm & 0.0427 & 4.1858 & 0.6103 & 3.7466 & 2.7967 \\
p value & & 0.15 & 0.212 & 0.03 & 0.126 \\
Significance & & $\mathrm{S}$ & $\mathrm{NS}$ & $\mathrm{S}$ & $\mathrm{S}$ \\
\hline
\end{tabular}

$\mathrm{SD}=$ standard deviation $\mathrm{S}=$ Significant at $\mathrm{p}<0.05 \mathrm{NS}=$ Non Significant

Table 8. Showing the mean area \% of caspase-3 expression and SD in all groups compared with control group.

\begin{tabular}{|c|c|c|c|c|c|}
\hline Groups/parameters & $\begin{array}{l}\text { Control } \\
\text { group }\end{array}$ & $\begin{array}{c}\text { Diabetic } \\
\text { group }\end{array}$ & Diabetic + vit - E group & Diabetic + Metformin group & Diabetic + Metformin + vit - E group \\
\hline Mean area $\%$ & 0 & 26.62 & 12.67 & 10.14 & 9.79 \\
\hline $\mathrm{SD} \pm$ & 0 & 3.1312 & 0.6010 & 2.0197 & 1.1006 \\
\hline $\mathrm{p}$ value & & 0.05 & 0.134 & 0.002 & 0.05 \\
\hline Significance & & S & NS & S & S \\
\hline
\end{tabular}

$\mathrm{SD}=$ standard deviation $\mathrm{S}=$ Significant at $\mathrm{p}<0.05 \mathrm{NS}=$ Non Significant

Table 9. Morphometric measurements (mean \pm SD) of Johnson score and seminiferous tubules (ST) in all groups.

\begin{tabular}{|c|c|c|c|c|c|}
\hline Groups/parameters & Control group & Diabetic group & $\begin{array}{c}\text { Diabetic } \\
+ \text { vit - E group }\end{array}$ & $\begin{array}{c}\text { Diabetic } \\
+ \text { Metformin group }\end{array}$ & $\begin{array}{c}\text { Diabetic + Metformin } \\
+ \text { vit - E group }\end{array}$ \\
\hline ST Diameter $(\mu \mathrm{m})($ mean \pm SEM $)$ & $45.134 \pm 4.352$ & $37.04 \pm 36.09^{\mathrm{a}^{*}}$ & $42.01 \pm 26.31^{\mathrm{a}, \mathrm{b}^{*}}$ & $39.60 \pm 9.59^{\mathrm{a}, \mathrm{b}^{*}}$ & $44.40 \pm 4.69^{\mathrm{a}, \mathrm{b}^{*}}$ \\
\hline Number of Leydig cells $/ 100 \mu \mathrm{m}^{2}$ & $22.31 \pm 3.05$ & $14.22 \pm 1.75^{\mathrm{a}^{*}}$ & $19.12 \pm 3.70^{\mathrm{a}, \mathrm{b}^{*}}$ & $17.95 \pm 8.67^{\mathrm{a}, \mathrm{b}^{*}}$ & $20.14 \pm 6.79^{\mathrm{a}, \mathrm{b}^{*}}$ \\
\hline Number of Sertoli cells/tubule & $33.68 \pm 2.96$ & $19.16 \pm 5.10^{\mathrm{a}^{*}}$ & $26.95 \pm 9.87^{\mathrm{a}, \mathrm{b}^{*}}$ & $25.75 \pm 6.87^{\mathrm{a}, \mathrm{b}^{*}}$ & $29.95 \pm 2.87^{\mathrm{a}, \mathrm{b}^{*}}$ \\
\hline Number of STs/field $\times 100$ & $29.88 \pm 2.61$ & $11.88 \pm 2.26^{\mathrm{a}^{*}}$ & $25.35 \pm 1.30^{\mathrm{a}, \mathrm{b}^{*}}$ & $27.21 \pm 4.10^{\mathrm{a}, \mathrm{b}^{*}}$ & $30.33 \pm 6.30^{\mathrm{a}, \mathrm{b}^{*}}$ \\
\hline Johnson score & $9.76 \pm 0.42$ & $5.47 \pm 0.12^{2^{*}}$ & $6.93 \pm 0.75^{\mathrm{a}, \mathrm{b}^{*}}$ & $8.74 \pm 0.66^{\mathrm{a}, \mathrm{b}^{*}}$ & $9.50 \pm 0.22^{\mathrm{a}, \mathrm{b}^{*}}$ \\
\hline
\end{tabular}

Results are given as mean \pm SEM. $\mathrm{n}=10$ for each group, ${ }^{*}$ significant difference between control group and diabetic group: $\mathrm{p}<0.05$, Absence of subscript indicates no significant difference. A Significant difference vs. control group a. b Significant difference vs. diabetic group II.

of Leydig cells and Sertoli cells were significantly decreased $(\mathrm{p}<0.05)$ in diabetic group (Table 9).

\section{Discussion}

We aimed in this study to compare the possible effects of metformin, or vitamin $\mathrm{E}$ or in combination with the vitamin $\mathrm{E}$ and metformin, on the testes of diabetic rats. Diabetes is one of chronic metabolic disease which leads to severe complications such as nephropathy, retinopathy and reproductive dysfunction [38] [39]. Treated animals with metformin showed partial recovery in body weight while, significant increase in body weight was shown with group treated with vitamin E ( $\mathrm{p}<0.001)$ more than the normal control rats. On the other hand, combined treatment with both metformin and vitamin $\mathrm{E}$ showed a significant recovery of the body weight compared to the diabetic control rats. Our data are in 
agreement with previous studies which indicate that vitamin $\mathrm{E}$ has effect on the body weigh in STZ-induced diabetic rats [40] [41]. In our study, the blood glucose levels have been decrease in metformin-treated diabetic rats than untreated diabetic rats $(\mathrm{p}<0.05)$, this result is in accordance with previous results [42]. Treatment with a combination of vitamin E with metformin showed recovery of the FSH, LH and testosterone to normal levels, while a significant difference ( $\mathrm{p}<$ 0.001 ) was showed in compared to the non-treated control diabetic rats. These results are typically in agreement with previous studies [43] [44].

From the results, there is no-significant difference $(\mathrm{p}>0.05)$ in compared to the normal non-diabetic rats after 8 weeks' treatment, where rats in vitamin $\mathrm{E}$ and combination treated groups showed near normal levels of TC, TG, HDL-c, LDL-c. All above results are as results in several studies [42].

The testicular antioxidant activity of CAT, SOD, and GSH in the STZ-treated diabetic rats was significantly $(\mathrm{p}<0.001)$ decreased, on the contrast, level of MDA was significantly increased compared to the non-diabetic rats $(\mathrm{p}<0.001)$. Our results are as previous studies, which showed that there was oxidative affection in diabetic patients in the form of increase testicular lipid peroxidation and decrease in testicular antioxidant mechanisms as CAT, SOD, and GSH activities [45]. Diabetic rats treated with metformin alone, significantly $(p<0.001)$ enhances the antioxidant parameters compared to the diabetic control rats. while, treatment of diabetic rats with combination of metformin and vitamin $\mathrm{E}$, led to normalization of the parameters, and there were significant $(\mathrm{p}<0.001)$ difference compared to the diabetic non-treated rats. Our results are in same with previous studies which have reported that, vitamin E significantly increases glutathione and decreases MDA levels in adult male rats [40] [46].

Diabetes mellitus (DM) is lead to release of reactive oxygen species (ROS) which leads to oxidative stress, that is due to presence of chronic hyperglycaemia [47] [48]. Hyperglycemia had been reported to cause functional and histological changes in target organs of diabetic patients, in addition, there are apparent effects of oxidative stress on diabetic testicular structure [49]. STZ-induced diabetes caused marked decrease, in serum insulin and that was detected in our study which would explain the decrease on androgen hormones. Also reduction of insulin levels has been reported to suppress the spermogenesis process by reduction of FSH rate [50]. Treatment with vitamin E increased the testosterone level, and this can be explained on the basis that vitamin E plays a key role in the steroidogenic process that stimulates testosterone synthesis [51]. In the present study, in diabetic untreated group, there were irregular semineferous tubules, other showed decrease in germ cell layers with separation of apoptotic spermatogenic cells into the tubular lumen. All above finding were studied by [52], other authors reported that spermatogenic cells were the target of diabetic disease as it causes apoptosis in spermatogenic epithelium and atrophy of the tubules [53], this confirmed by our study as there are significantly increase in the mean number of caspase -positive cells in the diabetic -untreated group in compared with the control group. While in the metformin-treated group, few tubules showed 
less caspase reaction. Also, the mean number of active caspase-3-positive cells was significantly decreased compared with diabetic group. Our study, show that the vitamin $\mathrm{E}$ diabetic group improved the spermatogenic tubules structure and decrease the mean number of caspase-positive cells. Histological finding in our study, of combined therapy by vitamin $\mathrm{E}$ and metformin in diabetic group has protected effect in testis as normalize the spermatogenic cells as control group. Studies explained the effects of combined vitamin E as antioxidant applications, it was showed that vitamin E only was insufficient in the protection of the testis from diabetic complication, but if be effective it must be used as combined therapy [54]. The enhancement of the combination treatment may be lead to synergistic effect between metformin and vitamin $\mathrm{E}$ in improvement in the glycemic state in addition to the antioxidant and hypolipidemic activities of vitamin $\mathrm{E}$ which leads to control of the disrupted redox state in the diabetic rats and fight the oxidative stress affection of the testes.

\section{Conclusion}

Results obtained from the present study revealed that using a combination of metformin and vitamin $\mathrm{E}$ was more effective in treatment of diabetic complications, especially on the reproductive system. So, antioxidants as vitamin $\mathrm{E}$ can be used as supporting protective therapy for reproductive dysfunction in diabetic patients and as potential novel therapeutic agents by diet.

\section{Acknowledgements}

The authors would like to thank Institute of Scientific Research and Revival of Islamic Heritage at Umm Al-Qura University, Makkah, KSA (Project No: 43509022) for the financial support.

\section{Disclosure and Conflicts Statement}

The author declares no conflicts of interest.

\section{References}

[1] Erejuwa, O.O., Sulaiman, S.A., Wahab, M.S., Sirajudeen, K.N.S., Salleh, M.S. and Gurtu, S. (2011) Effect of Glibenclamide alone versus Glibenclamide and Honey on Oxidative Stress in Pancreas of Streptozotocin Induced Diabetic Rats. International Journal of Applied Research in Natural Products, 4, 1-10.

[2] Rösen, P., Nawroth, P.P., King, G., Möller, W., Tritschler, H.J. and Packer, L. (2001) The Role of Oxidative Stress in the Onset and Progression of Diabetes and Its Complications. Diabetes/Metabolism Research and Reviews, 17, 189-212. https://doi.org/10.1002/dmrr.196

[3] Chakraborty, A., Chowdhury, S. and Bhattacharyya, M. (2011) Effect of Metformin on Oxidative Stress, Nitrosative Stress and Inflammatory Biomarkers in Type $2 \mathrm{Di}$ abetes Patients. Diabetes Research and Clinical Practice, 93, 56-62. https://doi.org/10.1016/j.diabres.2010.11.030

[4] Je, H.D., Shin, C.Y., Park, H.S., Huh, I.H. and Sohn, U.D. (2001) The Comparison of Vitamin C and Vitamin E on the Protein Oxidation of Diabetic Rats. Journal of 
Autonomic Pharmacolog, 21, 231-236. https://doi.org/10.1046/j.1365-2680.2001.00226.x

[5] Erejuwa, O.O., Sulaiman, S.A., AbWahab, M.S., Sirajudeen, K.N.S., Salleh, M.S. and Gurtu, S. (2011) Glibenclamide or Metformin Combined with Honey Improves Glycemic Control in Streptozotocin-Induced Diabetic Rats. International Journal of Biological Sciences, 7, 244-252. https://doi.org/10.7150/ijbs.7.244

[6] Erejuwa, O.O., Sulaiman, S.A. and Honey, M.S. (2012) A Novel Antioxidant. Molecules, 17, 4400-4423. https://doi.org/10.3390/molecules17044400

[7] Agarwal, A., Prabakaran, S.A. and Said, T.M. (2005) Prevention of Oxidative Stress Injury to Sperm. Journal of Andrology, 26, 654-660.

https://doi.org/10.2164/jandrol.05016

[8] Gheldof, N., Wang, X.H. and Engeseth, N.J. (2002) Identification and Quantification of Antioxidant Components of Honeys from Various Floral Sources. Journal of Agricultural and Food Chemistry, 50, 5870-5877. https://doi.org/10.1021/jf0256135

[9] Erejuwa, O.O., Sulaiman, S.A., Wahab, M.S., Salam, S.K., Salleh, M.S. and Gurtu, S. (2012) Hepatoprotective Effect of Tualang Honey Supplementation in Streptozotocin-Induced Diabetic Rats. International Journal of Applied Research in Natural Products, 4, 37-41.

[10] Erejuwa, O.O., Sulaiman, S.A., Wahab, M.S., Sirajudeen, K.N.S., Salleh, M.S. and Gurtu, S. (2011) Antioxidant Protection of Malaysian Tualang Honey in Pancreas of Normal and Streptozotocin-Induced Diabetic Rats. Annales d'Endocrinologie (Paris), 71, 291-296.

[11] Mohamed, M., Sulaiman, S.A., Jaafar, H. and Sirajudeen, K.N. (2011) Antioxidant Protective Effect of Honey in Cigarette Smoke-Induced Testicular Damage in Rats. International Journal of Molecular Sciences, 12, 5508-5521. https://doi.org/10.3390/ijms12095508

[12] Wu, M.S., Johnston, P., Sheu, W.H., Hollenbeck, C.B., Jeng, C.Y. and Goldfine, I.D. (1990) Effect of Metformin on Carbohydrate and Lipoprotein Metabolism in NIDDM Patients. Diabetes Care, 13, 1-8. https://doi.org/10.2337/diacare.13.1.1

[13] Moll, E., Veen, F. and Wely, M. (2007) The Role of Metformin in Polycystic Ovary Syndrome: A Systematic Review. Human Reproduction, 13, 527-537.

[14] Tartarin, P., Moison, D. and Froment, P. (2012) Metformin Exposure Affects Human and Mouse Fetal Testicular Cells. Human Reproduction, 27, 3304-3314. https://doi.org/10.1093/humrep/des264

[15] Wang, R.-S., Yeh, S., Tzeng, C.-R. and Chang, C. (2009) Androgen Receptor Roles in Spermatogenesis and Fertility: Lessons from Testicular Cell-Specific Androgen Receptor Knockout Mice. Endocrine Reviews, 30, 119-132. https://doi.org/10.1210/er.2008-0025

[16] Timurkaan, N., Yilmaz, F. and Timurkaan, S. (2011) Effects of Cottonseed Flour on Immunohistochemical Localization of Androgen Receptors (AR) in Rat Testes. Revue de Médecine Vétérinaire, 162, 13-17.

[17] D’andrea, M.R., Alicknavitch, M., Nagele, R.G. and Damiano, B.P. (2010) Simultaneous PCNA and TUNEL Labeling for Testicular Toxicity Evaluation Suggests that Detection of Apoptosis May Be More Sensitive than Proliferation. Biotechnic \& Histochemistry, 85, 195-204. https://doi.org/10.3109/10520290903547778

[18] Zeng, L., Kong, X.-T., Su, J.-W., Xia, T.-L., Na, Y.-Q. and Guo, Y.-L. (2001) Evaluation of Germ-Cell Kinetics in Infertile Patients with Proliferating Cell Nuclear Antigen Proliferating Index. Asian Journal of Andrology, 3, 63-66.

[19] Fernandes, G.S.A., Gerardin, D.C.C., Assumpção, T.A., Campos, K.E., Damasceno, 
D.C., Pereira, O.C.M. and Kempinas, W.D.G. (2011) Can Vitamins C and E Restore the Androgen Level and Hypersensitivity of the Vas Deferens in Hyperglycemic Rats? Pharmacological Reports, 63, 983-991. https://doi.org/10.1016/S1734-1140(11)70614-4

[20] Mahmoud, Y.K., Saleh, S.Y., El Ghannam, A.E.R.A. and Ibrahim, I.A. (2014) Biochemical Efficacy of Nigella Sativa Oil and Metformin on Induced Diabetic Male Rats. American Journal of Animal and Veterinary Sciences, 9, 277-284. https://doi.org/10.3844/ajavsp.2014.277.284

[21] Postic, C., Dentin, R. and Girard, J. (2004) Role of the Liver in the Control of Carbohydrate and Lipid Homeostasis. Diabetes \& Metabolism, 30, 398-408. https://doi.org/10.1016/S1262-3636(07)70133-7

[22] Pushparaj, P., Tan, C.H. and Tan, B. (2000) Effects of Averrhoa bilimbi Leaf Extract on Blood Glucose and Lipids in Streptozotocin-Diabetic Rats. Journal of Ethnopharmacology, 72, 69-76. https://doi.org/10.1016/S0378-8741(00)00200-2

[23] Ruperez, F.J., Garcia-Martinez, D., Baena, B., Maeso, N., Cifuentes, A. and Barbas, C. (2008) Evolution of Oxidative Stress Parameters and Response to Oral Vitamins $\mathrm{E}$ and $\mathrm{C}$ in Streptozotocin-Induced Diabetic Rats. Journal of Pharmacy and Pharmacology, 60, 871-878. https://doi.org/10.1211/jpp.60.7.0008

[24] Kianifard, D., Sadrkhanlou, R.A. and Hasanzadeh, S. (2011) The Histological, Histomorphometrical and Histochemical Changes of Testicular Tissue in the Metformin Treated and Untreated Streptozotocin-Induced Adult Diabetic Rats. Veterinary Research Forum, 2, 13-24.

[25] Figueroa, V.L., Diaz, C., Lopez-Ramos, M. and Garcia-Cervera, E. (2012) Glibenclamide-Pregnenolone Derivative Has Greater Hypoglycemic Effects and Biodistribution than Glibenclamide-OH in Alloxan-Rats. Biomedical Papers of the Medical Faculty of the University Palacky, Olomouc, Czechoslovakia (Biomed Paper), 156, 122-127. https://doi.org/10.5507/bp.2012.028

[26] Chen, X., Jing, J. and Tang, J. (2011) Extraction, Purification, Characterization and Hypoglycemic Activity of a Polysaccharide Isolated from the Root of Ophiopogon Japonicus. Carbohydrate Polymers, 83, 749-754.

https://doi.org/10.1016/j.carbpol.2010.08.050

[27] Sedlak, J. and Lindsay, R.H. (1968) Estimation of Total, Protein Bound and Non-Protein Sulfhydryl Groups in Tissue with Ellman's Reagent. Analytical Biochemistry, 25, 192-205. https://doi.org/10.1016/0003-2697(68)90092-4

[28] Aebi, H. (1984) Catalase in Vitro. In: Packer, L., Ed., Methods Enzymol, Academic Press, New York, 121-126.

[29] Misra, H.P. and Fridovich, I. (1972) The Role of Superoxide Anion in the Autoxidation of Epinephrine and a Simple Assay for Superoxide Dismutase. The Journal of Biological Chemistry, 247, 3170-3175.

[30] Ohkawa, H., Ohishi, N. and Yagi, K. (1979) Assay of Lipid Peroxides in Animal Tissues by Hiobarbituric Acid Reaction. Analytical Biochemistry, 95, 351-358. https://doi.org/10.1016/0003-2697(79)90738-3

[31] Ma, H., Jo, Y.J., Ma, Y., Hong, J.T., Kwon, B.M. and Oh, K.W. (2009) Obovatol Isolated from Magnolia Obovata Enhances Pentobarbital-Induced Sleeping Time: Possible Involvement of GABAA Receptors/Chloride Channel Activation. Phytomedicine, 16, 308-313. https://doi.org/10.1016/j.phymed.2008.12.007

[32] Bancroft, J.D. and Layton, C. (2013) The Hematoxylin and Eosin. In: Suvarna, S.K., Layton, C. and Bancroft, J.D., Eds., Theory \& Practice of Histological Techniques, 
7th Edition, Churchill Livingstone of El Sevier, Philadelphia, Ch. 10 and 11, 172-214. https://doi.org/10.1016/B978-0-7020-4226-3.00010-X

[33] Bayomy, N.A., Abd-Elmagyed, E.R. and Tawfik, S.M. (2008) Effect of Leflunomide (Avara) Drug on the Lung of Adult Male Albino Rats: A Histological and Immunohistochemical Study. Egyptian Journal of Histology, 31, 278-282.

[34] Jackson, P. and Blythe, D. (2013) Immunohistochemical Techniques. In: Suvarna, S.K., Layton, C. and Bancroft, J.D., Eds., Theory \& Practice of histological techniques, 7th Edition, Churchill Livingstone of El Sevier, Philadelphia. Ch. 18, 381-434. https://doi.org/10.1016/B978-0-7020-4226-3.00018-4

[35] Celik, O., Kutlu, O., Tekcan, M., Celik-Ozenci, C. and Koksal, I.T. (2013) Role of TNF-Related Apoptosis-Inducing Ligand (TRAIL) in the Pathogenesis of Varicocele-Induced Testicular Dysfunction. Asian Journal of Andrology, 5, 269-274.

https://doi.org/10.1038/aja.2012.112

[36] Soudmany, S., Yuvaraj, S., Malini, T. and Balasubramanian, K. (2005) Experimental Diabetes Has Adverse Effects on the Differentiation of Ventral Prostate during Sexual Maturation of Rats. The Anatomical Record Part A Discoveries in Molecular Cellular and Evolutionary Biology, 287, 1281-1289.

https://doi.org/10.1002/ar.a.20250

[37] Emsley, R., Dunn, G. and White, I.R. (2010) Mediation and Moderation of Treatment Effects in Randomised Controlled Trials of Complex Interventions. Statistical Methods in Medical Research, 19, 237-270. https://doi.org/10.1177/0962280209105014

[38] Take, G., Ilgaz, C., Erdogan, D., Ozogul, C. and Elmas, C. (2007) A Comparative Study of the Ultrastructure of Submandibular, Parotid and Exocrine Pancreas in Diabetes and Fasting. Saudi Medical Journal, 28, 28-35.

[39] Ricci, G., Catizone, A., Esposito, R., Pisanti, F.A., Vietri, M.T. and Galdieri, M. (2009) Diabetic Rat Testes: Morphological and Functional Alterations. Andrologia, 41, 361-368. https://doi.org/10.1111/j.1439-0272.2009.00937.x

[40] Punithavathi, V.R., Anuthama, R. and Prince, P.S. (2008) Combined Treatment with Naringin and Vitamin C Ameliorates Streptozotocin-Induced Diabetes in Male Wistar Rats. Journal of Applied Toxicology, 28, 806-813. https://doi.org/10.1002/jat.1343

[41] Kaplanoglu, G.T., Bahcelioglu, M., Gozil, R., Helvacioglu, F., Buru, E., Tekindal, M.A., Erdogan, D. and Calguner, E. (2013) Effects of Green Tea and Vitamin E in the Testicular Tissue of Streptozotocin-Induced Diabetic Rats. Saudi Medical Journal, 34, 734-743.

[42] Almeida, D.A.T., Braga, C.P., Novelli, E.L.B. and Fernandes, A.A.H. (2012) Evaluation of Lipid Profile and Oxidative Stress in STZ-Induced Rats Treated with Antioxidant Vitamin. Brazilian Archives of Biology and Technology, 55, 527-536. https://doi.org/10.1590/S1516-89132012000400007

[43] Nasrolahi, O., Khaneshi, F., Rahmani, F. and Razi, M. (2013) Honey and Metformin Ameliorated Diabetes-Induced Damages in Testes of Rat; Correlation with Hormonal Changes. Iranian Journal of Reproductive Medicine, 11, 1013-1020.

[44] Khaneshi, F., Nasrolahi, O., Azizi, S. and Nejati, V. (2013) Sesame Effects on Testicular Damage in Streptozotocin-Induced Diabetes Rats. Avicenna Journal of Phytomedicine, 3, 347-355.

[45] Chatterjee, K., Ali, D., Bera, K., Jana, S., Maiti, A., Ghosh, D. and Ghosh, A. (2013) Hyperglycemia-Induced Alteration in Reproductive Profile and Its Amelioration by the Polyherbal Formulation MTEC (Modified) in Streptozotocin-Induced Diabetic 
Albino Rats. Biomarkers and Genomic Medicine, 5, 54e66.

[46] Elham, G., Vahid, N., Gholamreza, N., Mozafar, K. and Mohammad, B. (2015) Study on the Effect of Royal Jelly on Reproductive Parameters in Streptozotocin-Induced Diabetic Rats. International Journal of Fertility and Sterility, 19, 113-120.

[47] Coskun, O., Kanter, M., Korkmaz, A. and Oter, S. (2005) Quercetin, a Flavonoi Antioxidant, Prevents and Protects Streptozotocin-Induced Oxidative Stress and $\beta$-Cell Damage in Rat Pancreas. Pharmacological Research, 51, 117-123. https://doi.org/10.1016/j.phrs.2004.06.002

[48] Fakher, S.H., Djalali, M., Tabei, S.M.B., Zeraati, H., Javadi, E. and Sadeghi, M. (2007) Effect of Vitamins A, E, C and Omega-3 Fatty Acids on Lipid Peroxidation in Streptozotocin Induced Diabetic Rats. Iranian Journal of Public Health, 36, 58-63.

[49] Abdella, E.A.B., Al Waleed, H., El Hassan, F., Asim, I., Salwa, K.M. and Samia, A. (2014) Investigate Evaluation of Oxidative Stress and Lipid Profile in STZ-Induced Rats Treated with Antioxidant Vitamin. Pharmacology \& Pharmacy, 5, 272-279. https://doi.org/10.4236/pp.2014.53034

[50] Kiyanifard, D., Hassanzadeh, S.H., Sadrkhanlo, R.A. and Farshid, A. (2010) Study of changes Structure Seminiferouse Tubule and Hormone Changes Gonadotropin Diabetic Rats. Medical journal of Medicine, 22, 239-248.

[51] Chen, H., Liu, J., Luo, L., Baig, M.U., Kim, J.-M. and Zirkin, B.R. (2005) Vitamin E, Aging and Leydig Cell Steroidogenesis. Experimental Gerontology, 40, 728-736. https://doi.org/10.1016/j.exger.2005.06.004

[52] Maritim, A.C., Sanders, R.A. and Watkins III, J.B. (2003) Diabetes, Oxidative Stress, and Antioxidants: A Review. Journal of Biochemical and Molecular Toxicology, 17, 24-38. https://doi.org/10.1002/jbt.10058

[53] Amaral, S., Moreno, A.J., Santos, M.S., Seica, R. and Ramalho-Santos, J. (2006) Effects of Hyperglycemia on Sperm and Testicular Cells of Goto-Kakizaki and Streptozotocin-Administered Rat Models for Diabetes. Theriogenology, 66, 2056-2067. https://doi.org/10.1016/j.theriogenology.2006.06.006

[54] Guneli, E., Tugyan, K., Ozturk, H., Gumustekin, M., Cilaker, S. and Uysal, N. (2008) Effect of Melatonin on Testicular Damage in Streptozotocin-Induced Diabetes Rats. European Surgical Research, 40, 354-360. https://doi.org/10.1159/000118032 